\title{
“A Walk in Between" \\ —On Hart Crane’s Imagination of Representational Space and Representations of Space in The Bridge
}

\author{
Billy Bin Feng Huang \\ National Chengchi University, Taipei, Taiwan (R.O.C.)
}

\begin{abstract}
In this paper, Henri Lefebvre's theorizations about representational space and representations of space will be employed to examine Hart Crane's imagination of them in The Bridge. First, according to Lefebvre, representations of space are created with violence for the purpose of accumulating capital. On the other hand, representational space is directly lived or affectively felt, opened up by inhabitants' imagination. In addition, Lefebvre points out that in abstract space, representational space will be invaded by representations of space. In The Bridge, Crane’s affective experience with the Brooklyn Bridge or the subway indicates that he treats New York as a representational space. Besides, Crane expresses his concern for how capitalism has encroached on it. It would seem that Crane has followed Lefebvre's line of thinking in The Bridge. However, it is actually a specious analysis because both the Brooklyn Bridge and the subway are representations of space. And in this long poem, Crane feels the urban space through history, which plays a key role in creating representations of space. Thus, we can conclude that Crane is actually taking "a walk in between" in The Bridge. With his imagination, Crane has combined representations of space and representational space into his own poetic vision.
\end{abstract}

Keywords: (Henri) Lefebvre, representations of space, representational space, (Hart) Crane, The Bridge

Urban design ... is structurally produced out of the basic contradiction between capitalist social and property relations (and their specifically urban manifestations) and the concomitant necessity for collective action.

-J. Scott and S. T. Roweis

“Urban Planning in Theory and Practice: A Reappraisal” (1997)

[The Brooklyn Bridge is] the first suspension bridge to use steel-wire cables and one of the first to use pneumatic caissons for foundations... The bridge was designated as a national historic landmark by the United States Department of the Interior in 1964. —“Brooklyn Bridge”

The Encyclopedia Americana (1982)

Billy Bin Feng Huang, Ph.D. Candidate, English Department, National Chengchi University. 


\section{Introduction}

In 1923, the idea of composing The Bridge first took shape in Hart Crane's mind. Crane explained to Gorham Munson the intention of this book-length poem, "Very roughly, it [The Bridge] concerns a mystical synthesis of 'America'. History and fact, location, etc. the bridge, symbol of our constructive future, our unique identity...” (Crane, 1952, p. 124). Crane intended for The Bridge to synthesize the American experiences, and clearly he chose the Brooklyn Bridge as its central image because he had not only deemed it as a historic landmark in America but also marveled at the technological achievement of constructing it, as the entry of "Brooklyn Bridge" in The Encyclopedia Americana suggests. In addition, around the image of the Brooklyn Bridge in The Bridge is Crane's portrayal of the urban space in New York. On the other hand, Scott and Roweis have pointed out that urban space, in spite of the contradictions between social and property relations, should be based on the need for collective action in capitalist society. In a way, they think capitalist society has created urban space to facilitate capitalism-based collective action. If so, in capitalist society, urban design has to be all about "the production of urban meaning", which "has typically supported shifts in capital accumulation ... in ways crucial to the reinforcing of dominant interests” (King, 1988, p. 445). In terms of how capitalism creates urban space and how the individual interacts with it, Henri Lefebvre has developed the concepts of representational space and representations of space. In this paper, the author intends to employ Lefebvre's theorizations about representational space and representations of space. And the main objective is to examine Crane's imagination of them both in The Bridge. To be more specific, the author will first trace Crane's line of thinking about New York's urban landscape. On the other hand, in theorizing about the two concepts, Lefebvre has gained an insight into the inner capitalism logic in urban space. By juxtaposing Crane and Lefebvre, the author intends to find out whether the former's observation coincides or contradicts with the latter's insight.

\section{Lefebvre's Concepts of Representations of Space and Representational Space}

First of all, Karl Marx and Friedrich Engels explore the relationship between productive forces and cities in their The Communist Manifesto; above all, they ascribe them both to the bourgeoisie:

The bourgeoisie cannot exist without constantly revolutionizing the instruments of production... The bourgeoisie has subjected the country to the rule of the towns. It has created enormous cities, has greatly increased the urban population as compared with the rural, and thus rescued a considerable part of the population from the idiocy of rural life... The bourgeoisie ... has agglomerated population, centralized means of production, and has concentrated property in a few hands... The bourgeoisie ... has created more massive and more colossal productive forces than all the preceding generations together. (1992, pp. 6-8) ${ }^{2}$

What Marx and Engels have done is to connect the dots, or to delineate a chain reaction: The bourgeoisie has revolutionized the instruments of production and created tremendous productive forces; as a consequence, it has agglomerated population and thus created large cities. Following Marx and Engels’ line of thinking, Lefebvre believes that "the city ... allows the concentration over a limited space of the means of production: tools, raw

\footnotetext{
${ }^{1}$ Italics is made by the author of this paper.

${ }^{2}$ In our age of the meltdown of communism, Marx and Engels' Manifesto has inevitably raised quite a few doubts. David Mclellan has commented rather fairly on it, thinking it "belongs to the springtime of socialist thought. As a propaganda document, some of its theses are undoubtedly simplistic... The Manifesto combines the genres of dramatic theater with historical analysis. The result is a classic whose powerful vision has inspired generations of militants” (Mclellan, 1992, pp. xvi-xvii).
} 
materials, labor". He later points out, "As Marx explained, urban concentrations have accompanied the concentration of capital” (Lefebvre, 1996, p. 69). That is, "the city constitutes a means of production” (Lefebvre, 1991, p. 88). Indeed, one of Lefebvre’s main emphases is "social space”, which "implies ... the possibility of accumulation... Evidence in support of this proposition ... is overwhelmingly confirmed by urban space... Urban space gathers crowds, products in the markets, acts and symbols. It concentrates all these, and accumulates them" (p. 101). All in all, what Lefebvre has argued for corresponds to Marx and Engels' projection The Manifesto: the city, responsible for the concentration of capital as well as population, has become part of the machinery of production. Paul Walker Clarke, tracing the economic currency in modern cities, also concludes, "Capitalist cities are cities of constant flux" of capital... By mid-nineteenth century, the dominant economic character of cities shifted from centers of commerce to centers of production” (Clarke, 2003, p. 30). Soja further points out that production and spatiality are actually inscribed in our life, “....social relations of production and class can be reconfigured and possibly transformed through the evolving spatiality which makes them concrete... Social and spatial structures are dialectically intertwined in social life...” (Soja, 1989, p. 127). It is from this perspective that Soja proposes his "materialist interpretation of spatiality"; namely, "spatial structures and relations are the concrete manifestations of social structures and relations", or "the mode of production" (p. 127). In other words, the urban space is created to stabilize the social relations of production as well as the continuous accumulation of capital. Above all, it can more or less "obscure 'class consciousness' and thus help demobilize the workers” to prevent class struggle, as Lefebvre suggests in The Production of Space (1991, p. 89) ${ }^{3}$.

Later, Lefebvre furthers his analysis of urban space by introducing the concept of violence, “...under the dominion of capitalism and of the world market, it [violence] assumed an economic role in the accumulation process...” (1991, p. 276). Basically, Lefebvre attempts to inform us of a crucial fact about violence: it is in fact the very lifeblood of the space of accumulation or investment (1991, p. 277). That is, violence plays a significant role in creating urban space. Following up this notion of violence, Lefebvre proposes the two concepts of representations of space and representational space: representations of space constitute "conceptualized space, the space of scientists, planners, urbanists, technocratic subdividers and social engineers, as of a certain type of artists with a scientific bent” (p. 38). In other words, representations of space are carefully designed; they are creations of urban or land developers. "Land planners play the land use game in an arena with other players... [and they] also act as game managers, drafting and enforcing the rules of the game...” (Kaiser, Godschalk, \& Chapin, 1995, p. 5, italics mine). While doing so, they are creating representations of space. Lefebvre later comments on representations of space, "Representations of space must therefore have a substantial role and a specific influence in the production of space. Their intervention occurs by way of construction-in other words, by way of architecture...” (Lefebvre, 1991, p. 42). If representations of space are final results of architectural projects, then we have to note that "architects today work mainly under corporate patronage, urban planners, real estate developers... New architecture and urban forms are ... consumer products” (Zukin, 2003, p. 178). That is to say, Lefebvre clearly targets representations of space when he observes how urban space is created for the

\footnotetext{
${ }^{3}$ In his The Urban Revolution, Lefebvre proposes that the appearance of industrial capital is soon followed by the emergence of the capital city, which is "often a shapeless town, a barely urban agglomeration, a conglomerate, or conurbation like the Ruhr Valley". It also "serves a prelude to a critical zone. At this moment ... the increase in industrial production is superimposed on the growth of commercial exchange and multiplies the number of such exchanges” (Lefebvre, 2003, pp. 13-14).
} 
purpose of accumulating capital, in the course of which violence fully exerts its influence. Architectural projects, based on capitalism, have violently created representations of space and opened up our urban space. However, by no means does it indicate that representations of space exclusively comprise our urban space, for Lefebvre argues, “Even "neocapitalism or 'organized' capitalism, even technocratic planners and programmers, cannot produce a space with a perfectly clear understanding of cause and effect, motive and implication” (1991, p. 37). The main reason is that representations of space are based on "a system of verbal (and therefore intellectually worked out) signs” (1991, p. 39). Friedrich Nietzsche gives his own description of this system, "A mobile army of metaphors, metonyms, and anthropomorphisms ... which after long use seem firm, canonical, and obligatory to a people" (Nietzsche, 1954, pp. 46-47). Lefebvre expressly shows his disbelief in this system (1991, p. 139); he is convinced that space is nothing like a readable text, and that "even if the reading of space (always assuming there is such a thing) comes first from the standpoint of knowledge, it certainly comes last in the genesis of space itself" (1991, p. 139 ). For Lefebvre, space is "produced before being read... [and] in order to be lived by people with bodies and lives in their own particular urban context” (1991, p. 143, italics mine). To put it in a nutshell, space isn't just created; it may be lived by people. Hence, representations can't fully account for the production of urban space. That's why he proposes the concept of representational space:

...space as directly lived through its associated images and symbol, and hence the space of "inhabitants" and "users", but also of some artists and perhaps of those, such as a few writers and philosophers... This is the dominated-and hence passively experienced—space which the imagination seeks to change appropriate ... representational spaces ... tend towards more or less coherent systems of non-verbal symbols and signs. (Lefebvre, 1991, p. 39)

Lefebvre later adds, "Representational space is alive: it speaks. It has an affective kernel or center: Ego, bed, bedroom, dwelling, house; or: square, church, graveyard. It embraces the loci of passion, of action and of lived situations, and thus immediately implies time” (1991, p. 42). Andy Merrifield regards representational space as "the directly lived space of everyday experience..., [which doesn't] involve too much 'head': it's more felt than thought” (Merrifield, 2002, p. 90, italics mine). Merrifield's observation may be associated with what Christian Norberg-Schulz terms "the spirit of place", which refers to a local character artists and writers have found inspiration in, or a certain environmental character one is exposed to while "dwelling” in a place (Norberg-Schulz, 2003, pp. 123-124). That is, representational space must be lived, so that its emotional value or character can be extracted.

In brief, representations of space basically refer to architecture designed by urban planners from a rationally conceivable perspective; ${ }^{4}$ representational space, opened up by inhabitants' imagination, is directly lived or affectively felt. As Lefebvre suggests in The Urban Revolution, the former is created on a global level, while the latter has to be comprehended on a local, private level (2003, pp. 78-86).

To string together the two concepts of representations of space and representational space, Lefebvre proposes another term, "abstract space" in his The Production of Space. It is "the space of the bourgeoisie and of

\footnotetext{
${ }^{4}$ Charles Jencks speaks of the form of architecture in his Architecture 2000: Predictions and Methods. He argues that in architecture form must "express" function. And over the centuries the idea of being "expressive" has come to mean merely "readable". Drawing on Jencks' point of view, Lefebvre, in his The Production of Space, argues, "The architect is supposed to construct a signifying space wherein form is to function as signifier to signified; the form, in other words, is ... espoused by most 'designers'...” See Charles Jenkins (1971), Architecture 2000: Predictions and Methods, pp. 114-116, and Lefebvre (1991), p. 144.
} 
capitalism, bound up as it is with exchange (of goods and commodities, as of written and spoken words, etc.) depends on consensus more than any space before” (1991, p. 57). Here, Lefebvre’s “abstract space” may be juxtaposed with Georg Simmel's viewpoint of money: money, having taken the place of God, has become an absolute criterion for commodity value. This is how an order of exchange is established (Simmel, 1990, pp. 236-237). Clearly, Lefebvre's abstract space is completely built upon this order of exchange. As this order of exchange prevails, Lefebvre mentions in The Production of Space,

...labor [falls] prey to abstraction... Abstract space functions "objectally... Formal and quantitative, it erases distinction... Differences, for their part, are forced into the symbolic forms of an art that is itself abstract. A symbolism derived from that mis-taking of sensory, sensual and sexual which is intrinsic to the things/signs of abstract space finds objective expression in derivative ways: monuments have a phallic aspect, towers exude arrogance, and the bureaucratic and political authoritarianism immanent to a repressive space is everywhere. (1991, p. 49, italics mine)

Here Lefebvre gives us a case scenario where the monetary order of exchange predominates: everything becomes a quantified abstraction (i.e., a price), as every difference is erased; the same order also represses our sensory, sensual and sexual experiences and objectifies them into architecture in a derivative fashion. In a way, these experiences have been "specularized” in abstract space, as Lefebvre terms it (1991, pp. 285-291). The final outcome in abstract space is, "The representation of space, in thrall to both knowledge and power, leaves only the narrowest leeway to representational spaces...” (Lefebvre, 1991, p. 50). That is, in abstract space, representations of space will inevitably encroach on representational space.

\section{Like Lefebvre, Crane's Seemly Puts the Representations of Space Over the Representational Space in The Bridge}

Now, it should be clear that Lefebvre puts spatiality over time. "For Lefebvre ... space holds the promise of liberation: liberation from ... social repression and exploitation ... liberation into desire” (Smith, 2003, p. xiii). That is, in a spatial context, Lefebvre has gained an insight into the inner logic of capitalism and sought to figure out a solution. ${ }^{5}$ Here comes my critical question: Crane's The Bridge gives a portrayal of the urban landscape of New York. In this long poem, does his imagination of the representations of space and representational space follow the Lefebvrian trajectory of urban spatiality? Seemly, it does! In the course of Crane's composition of The Bridge, he "took up residence at 110 Columbia Heights, overlooking Brooklyn Harbor ... he looked out over the Brooklyn water-front ... there came to him many of the impressions and images...” (Butterfield, 1969, p. 123). As we know, "poetry (or a poem) [is] directly descriptive of the real physical city as an experiential entity, or poetry [should be] descriptive of people whose lives are obviously affected by their experience of that entity" (Johnston, 1984, p. xvii, italics mine). For Crane, the urban space of New York certainly qualifies as an experiential entity, and he certainly has affective attachment to it. For Crane, the Brooklyn Bridge is the center of New York. Watching it day and night, Crane has given it such a description in "To Brooklyn Bridge" of The Bridge:

And Thee, across the harbor, silver-paced

\footnotetext{
${ }^{5}$ Manuel Castells has critiqued Lefebvre's theorizations about urban space, "Lefebvre comes closer and closer, through a rather curious intellectual evolution, to an urbanistic theorization of the Marxist problematic”. See Manuel Castells (1977), The Urban Question: A Marxist Approach, p. 87.
} 
As though the sun took step of thee, yet left

Some motion ever unspent in thy stride,

Implicitly thy freedom staying thee!

Again the traffic lights that skim thy swift

Unfractioned idiom, immaculate sigh of stars,

Beading thy path—condense eternity:

And we have seen night lifted in thine arms.

Under thy shadow by the piers I waited;

Only in darkness is thy shadow clear.

The City's fiery parcels all undone,

Already snow submerges an iron year...

O Sleepless as the river under thee,

Vaulting the sea, the prairies' dreaming sod,

Unto us lowliest sometimes sweep, descend

And of the curveship lend a myth to God. (Crane, 1930, lines 13-16, 33-44)

In the quoted stanzas, Crane portrays the images of the Brooklyn Bridge in the day and in the night. Indeed, "while the cityscape necessarily grounds the text, it serves primarily as background; the bridge itself becomes his point of focus - the very axis of the vast city itself " (Wargacki, 2006, p. 331). Paul Giles, commenting on the line, "And of the curveship lend a myth to God," thinks the Brooklyn Bridge acts as a cross. "The Bridge is here described in such grandiose terms that it is as if it were not only crossing the harbor but also harboring a cross, assuming its shoulders...” (Giles, 1986, p. 83). Sherman Paul also echoes Giles' view, "The evocation of divinity is powerful in Crane's lines... For the bridge, framed by divinity, is also the instrument with which we entreat divinity...” (Paul, 1972, p. 185). Apparently, Crane is seeking divinity in the vast urban space of New York, and the Brooklyn Bridge has become a pivotal image, or a key to his quest, as Crane himself stated, "I feel persuaded that here [New York and the other places in America] are destined to be discovered certain as yet undefined spiritual qualities... And in this process I like to feel myself as a potential factor...” (Crane, 1966, p. 219, italics mine). The reason why Crane thinks of himself as "a potential factor" is that in his imagination New York is a city replete with divine and spiritual potentialities, and that it behooves him to tap them. As for the Brooklyn Bridge, it has simply opened up an avenue for his search. That is, Crane, living in New York, has painted its cityscape with his imagination. If so, it would appear that Crane has demarcated his own representational space in New York, the space that he lives and imagines, and the space for his artistic creation as well. Above all, as he is dying to be connected with "the spirit” of New York, as Norberg-Schulz has termed it, he has brought himself closer to his own representational space.

Crane's ties with his representational space have been strengthened by his subway ride in "The Tunnel" of The Bridge:

Ten blocks or so before? But you find yourself

Preparing penguin flexions of the arms,

As usual you will meet the scuttle yawn:

The subway yawns the quickest promise home. 


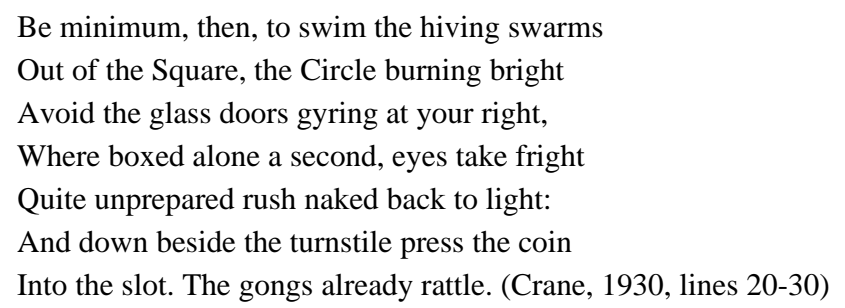

Evidently, Crane physically makes every move with the subway system. Sunny Slater argues that in The Bridge, the "everydayness" of the subway system has to be emphasized. As far as Crane is concerned, the subway is a powerful symbol of the modern machine. "Critics tend to agree that "The Tunnel" conveys how subway space has dramatically shaped urban subjectivity” (Staler, 2010, pp. 72-73). As an urban poet, Crane considers the subway system part of his everyday life, or even a qualification for his subjectivity in New York. If so, then his subway ride is part of his process of physically dwelling in New York. Lefebvre's representational space must be dwelled, as we've mentioned previously. And Lefebvre's conception could be further explicated by Gaston Bachelard's "psychology of the house" in his The Poetics of Space. Bachelard first points out, "A house is imagined as a vertical being. It rises upward... Verticality is ensured by the polarity of cellar and attic...they open up two very different perspectives for a phenomenology of the imagination” (1994, p. 17). Then Bachelard highlights the importance of physically moving between the attic and the cellar:

Then there are always the stairways... We always go down the one that leads to the cellar, and it is this going down that we remember, that characterizes its oneirism... Lastly, we always go up the attic stairs, which are the steeper and more primitive. For they bear the mark of ascension to a more tranquil solitude. (1994, pp. 25-26)

According to Bachelard, as the inhabitant's body is moving physically around the house, it will inevitably leave different marks on the inhabitant's psychology, triggering his or her different imaginations about different parts of the house. Bachelard believes that only by doing so will the house become "a psychic state", and it is at this moment when "it bespeaks intimacy" because "it ... possesses certain kinesthetic features" (1994, pp. 72-73), namely, the inscriptions of the physical movements of the inhabitant's body. That is, the inhabitant's body must play a crucially interfacial role in his or her relationship with the space. Bachelard's emphasis on physical living does help us see Lefebvre's representational space in perspective: in representational space, one's body must take the place of his head. If so, while Crane is making his way through the subway station and exercising his imagination, then the subway space will bear the "kinesthetic features", according to Bachelard's terminology. Doubtless, it will integrate the subway space into Crane’s representational space.

Having demarcated his own representational space, Crane has taken quite a bit exception to the representations of space in New York. It would seem that Crane, almost like Lefebvre, has taken notice of the intrusion of the representations of space. First of all, by 1900 New York had become "the locus of trade and finance", or an industrial city where "the increments derived from land, capital, and association went ... to those who had a legal title to the land and the productive machinery" (Mumford, 1945, p. 23). Mumford also concludes, "The forces that have made New York dominant are inherent in our financial and industrial system" (1945, p. 23). Crane does express his concern for the gradual industrialization and commercialization of New York. For example, in the beginning of "The River" of The Bridge, he writes: 
Stick your patent name on a signboard

brother-all over-going west-young man

Tintex - Japalac - Certain-teed Overall ads

and lands sakes! under the new playbill ripped

in the guaranteed corner-see Bert Williams what?

...while an Express makes time like

SCIENCE-COMMERCE and the HOLYGHOST

RADIO ROARS IN EVERY HOME WE HAVE THE NORTHPOLE

WALLSTREET AND VIRGINBIRTH WITHOUT STONES OR

WIRES OR EVEN RUNning brooks connecting ears (Crane, 1930, lines 1-5, 12-16)

In the quoted stanzas, Crane's protest against capitalism simply manifests itself. "His eyes are assaulted by advertising billboards, and his mind depressed with thoughts of the degeneration of art, religion, and national feeling, and the distortions of science and commerce” (Weber, 1948, p. 354). An even more striking instance of Crane's protest against commercialism is in "The Quaker Hill”:

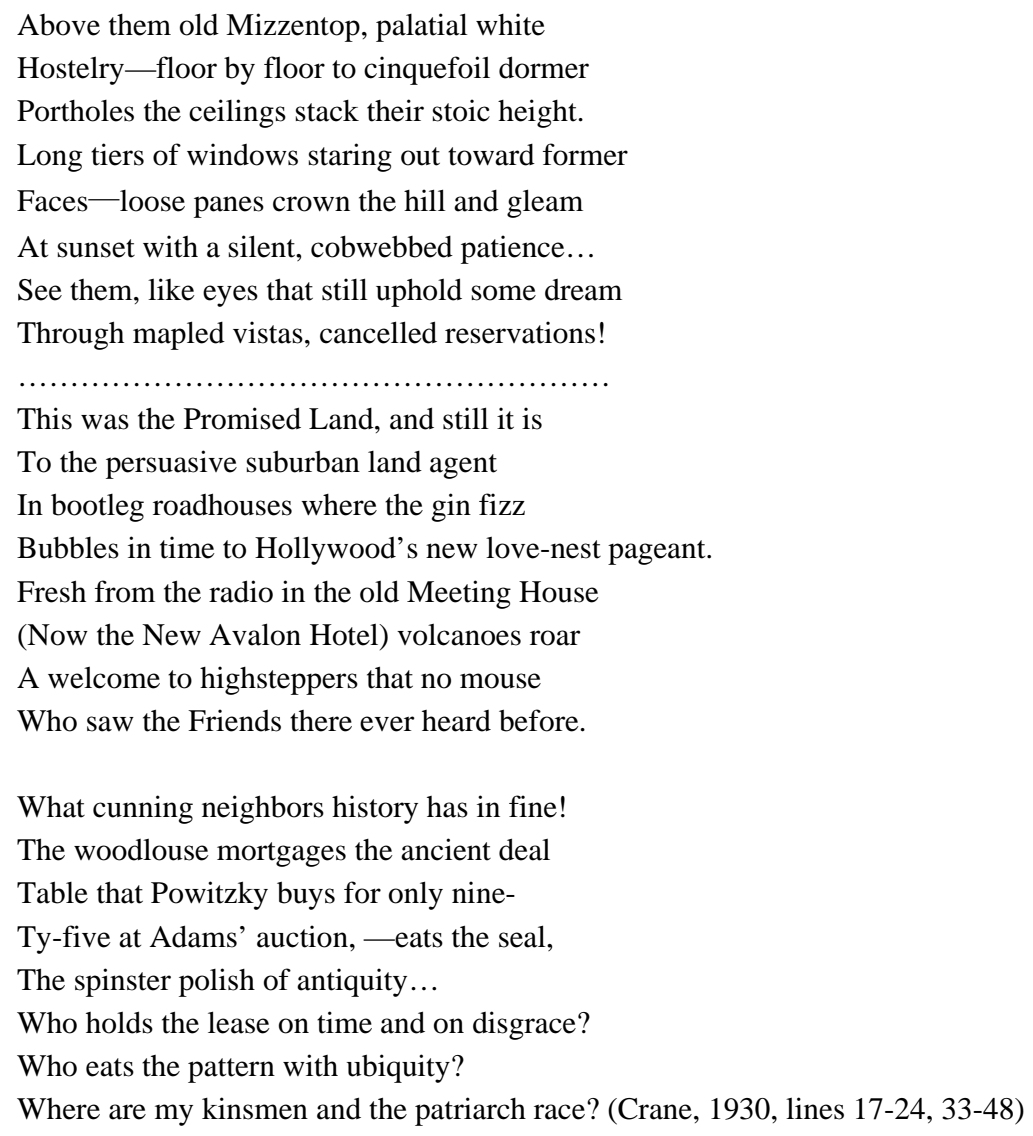

In this part of The Bridge, Crane is "developing the theme of the glorious past beclouded by a sorry present" (Weber, 1948, p. 371); he is aiming at the "savage indictment of American 'materialism' and 'industrialism'..." (Lewis, 1967, p. 243). As Quaker Hill, a historically significant region, has become the site of a golf course with a luxurious hotel next to it, Crane is inveighing against Powitzky, an eager capitalist, whom Crane compares to "a woodlouse" in his ravenous desire to consume Quaker Hill. At the same time, "he must visualize the history of 
the landscape” (Monacell, 2011, p. 123) ${ }^{6}$ That is, while Crane is gazing at this landscape, his imagination is taking him back to the palatial, old hostelry of Mizzentop. Picturing what a magnificent structure it used to be, Crane is also bemoaning the invasion of capitalism in this region. Doubtless, Lefebvre would categorize a golf site and the New Avalon Hotel as the representations of space. Viewing their entry into the private space created out of his own imagination, Crane seems to be repeating Lefebvre's of concern: representational space is shrinking as a consequence of representations of space. Kristiaan Versluys argues, "Modern city poetry is ... written ... from an intra-urban vantage-point” (1987, p. 225). And for Crane, New York is the locus of the unexpectedly unpleasant, a broken world (Versluys, 1987, pp. 17, 225).

\section{Crane's “Walk in Between”: The Truth About His Imagination of the Representations of Space and Representational Space in The Bridge}

So far, it has appeared that we are able to draw this conclusion: by and large Crane's imagination of the representations of space and representational space coincides with Lefebvre's projections for urban landscape. However, if we did draw this conclusion, we would be missing the bigger picture. To be more exact, it would be as if we were piecing together only fragments of Crane's The Bridge to tease out a specious, one-sided analysis. First of all, in The Bridge, "Crane returns again and again to treat modern means of transportation... He was not willing, like Eliot, to lament the advent of the machine age” (Uroff, 1974, p. 10). The most noticeable examples would be how he has thematicized the Brooklyn Bridge and the subway system. In the case of the latter, it is probable that Crane might take an ambivalent attitude, treating it as the evil twin of the Brooklyn Bridge (Weber, 1948, p. 372). As for the former, however, Crane's attitude is much clearer: he regards it as "the longest and highest span of its time, a great engineering spectacle, a monument and symbol of America's scientific and technological advance” (Arpad, 1967, pp. 80-81). In other words, Crane’s attitude is what Leo Marx has termed the "technological sublime" (Marx, 1964, p. 195); he simply marvels at the sublimity and novelty of the modern technology of constructing the Brooklyn Bridge. And the only reason why the technology was employed to build the Brooklyn Bridge was the facilitation of transportation. "In 1866, Manhattan Island was connected with Brooklyn and the rest of Long Island only by ferries". "The urban masses had to have a means of rapid and cheap transportation” (Current, Williams, \& Freidel, 1965, pp. 505-506). The Brooklyn Bridge was built in response to this public demand. In Justice, Nature, and the Geography of Difference, Harvey notices that in capitalist society, "it takes the production of a specific set of space relations (like a rail network) in order to annihilate space by time” (1996, p. 241). Doing so "often entails, therefore, not only th destruction of ways of life and social practices built around preceding time-space systems, but the 'creative destruction' of a wide range of physical assets embedded in the landscape” (Harvey, 1996, p. 241). "The elimination of spatial barriers and the struggle to 'annihilate space by time' is essential to the whole dynamic of capital accumulation...” (Harvey, 1996, p. 241). Harvey basically informs us that any transportation system, such as the railroad network, has to be conceived and

\footnotetext{
${ }^{6}$ As a matter of fact, Monacell's argument is based on suburbanization, as he states, "In his 1930 sequence The Bridge, Hart Crane portrays suburbanization as a destructive force on American history”. He also draws on Kenneth T. Jackson's observation: by 1900 railroad commuters lived in standardized houses, which "set a suburban standard rather than an urban standard for achievement-oriented Americans”. He also quotes John Archer, “...the standardization and commodification of the house led many to doubt its capacity ... of individualized American selfhood”. See Monacell (2011), p. 123; Kenneth T. Jackson (1985), Crabgrass Frontier: The Suburbanization of the United States, p. 137; John Archer (2008), "Suburban Aesthetics Is Not an Oxymoron”, in Worlds Away: New Suburban Landscape, p. 137.
} 
built by the force of violence, and that its aim is to accumulate capital. According to Lefebvre, it will surely fall into the category of representations of space. As the author has argued previously, Crane might view the urban space of New York as his representational space because he has inhabited, experienced, and imagined it. However, it is indeed a blatant absurdity, by the Lefebvrian criteria, to treat the Brooklyn Bridge, a major representation of space, as the central image in it.

Margaret Dickie states in her "The Backward Flight of The Bridge", "The bridge in Crane's term was a completed structure, a symbol of completion and wholeness...” (1985, p. 95). Arpad, drawing on Mumford's ideas, defines Dickie's so-called "a symbol of completion and wholeness" as "the Hegelian thesis-antithesis-synthesis". "Against the massive granite towers, a stone architecture of the past with Gothic arches and shadowy solids, stands the spidery web of steel, an architecture of the future, light, airy, a composition of voids rather solids" (1967, p. 79). ${ }^{7}$ All in all, the Brooklyn Bridge, in Crane's imagination, is a connection between the past and the future. Crane himself also stated, "The deliberate program, then, of a "break" with the past or tradition seems to me to be a sentimental fallacy...” (1952, p. 218). This is why The Bridge, in addition to technological wonderment, is sprinkled with historical references; "the bulk of Crane's comparison between past and present [in The Bridge] is concerned with the history of America” (Buelens, 1992, p. 251, italics mine). Stalter also observes, "Throughout The Bridge, Crane connects literary innovators with technological innovations. "Cape Hattaras” pairs the airplane and Walt Whitman...”8 As a matter of fact, here the airplane is the one the Wright brothers invented and tested:

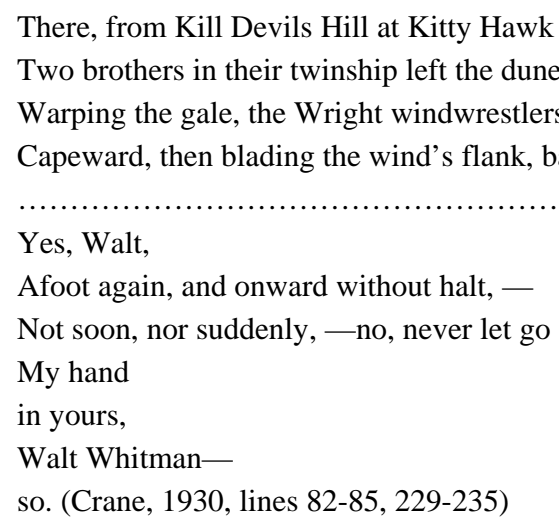

Stalter also points out, “Cutty Sark” features a sailor thought to be Herman Melville:

I met a man in South Street, tall-

a nervous shark tooth swung on his chain.

His eyes pressed through green glass

— green glasses, or bar lights made them

\footnotetext{
${ }^{7}$ Vincent Quinn claims that the Brooklyn Bridge, for Crane, "is a symbol of man's incessant search for an epiphany, a sign, of his higher fulfillment... Man's need for an idealistic faith and the power of the bridge to aid in its achievement are acknowledged”. See Vincent Quinn (1963), Hart Crane, pp. 80-81.

${ }^{8}$ Dickran Tashjian argues that embracing their tecnology is actually American modernists' strategic break from their European past. It helped them envision a tradition not beholden to Europe. See Dickran Tashjian (1975), Skyscraper Primitives: Dada and the American Avant-Garde 1910-1925, p. 128.
} 


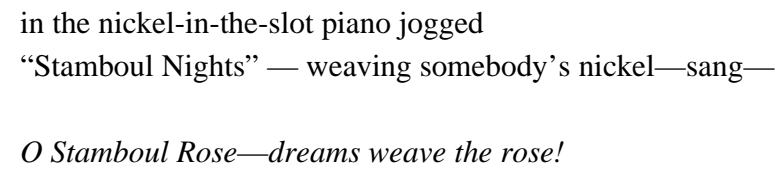

Murmurs of Leviathan he spoke, and rum was Plato in our heads... (Crane, 1930, lines 1-4, 11-15)

In these sections of The Bridge, Crane feels these urban spaces by the agency of history, just as he does in “The Quaker Hill”. When it comes to representational space, a key factor is always how the individual seamlessly feels and lives it. However, historical knowledge actually creates a distance between the individual and the space, stopping him or her from naturally and pleasurably dwelling in it (Chiou, 2009, p. 74). Anne Vernez Moudon also states, "The study of urban history has expanded remarkably over the past two decades to include now significant information for the practicing urban designer” (Moudon, 2003, p. 368). According to Moudon’s observation, history is in fact an essential element of urban design, or the design of representations of space. That's why it precludes any possibility of directly accessing representational space. Thus, by Lefebvre's theories, Crane's attempt to access representational space through history has certainly become a glaring error. That is, Crane has erroneously historicized his representational space. Perhaps we should put it this way: when Lefebvre speaks of representational space, he emphasizes the inhabitant's affection and imagination. At the same time, he also articulates for the fact that it is a privately-felt space based on non-verbal system. In representational space, the inhabitant's physical body is the key, not his intellectual head. Somehow Crane has constructed his representational space, a cityscape of his affection and imagination, on his understanding of American history, a system of highly verbal knowledge. Reversely, Crane's brain has taken the place of his body.

It is high time that we revealed the truth of Crane's imagination of representational space and representations of space: Crane has taken “a walk in between”, as the title of this paper suggests. He has erased the distinction between them; he has inserted the Brooklyn Bridge and the subway system, two representations of space, into his representational space, which has somehow been historicized. As I have stated previously, Lefebvre, in positing the two terms, has also presented his insight into the inner logic of capitalism. In a way, Crane has dispensed with this logic and substituted it for his "logic of metaphor", a term he gives such a definition:

The motivation of the poem must be derived from the implicit emotional dynamics of the materials used, and the terms of expression employed are often selected less for their logic (literal) significance than for their associational meanings. Via this and their metaphorical interrelationships, the entire construction of the poem is raised on the organic principle of a "logic of metaphor," which antedates our so-called pure logic, and which is the basis of all speech, hence consciousness and thought-extension. (1966, p. 221)

Basically, Crane's "logic of metaphor" is the extension of his consciousness, or a way of pushing his imagination to its limit; it is also the Crane's way of forging metaphorical interrelationships on the basis of associational meanings in his poem. Crane has sharpened his skills of using the logic of metaphor in his other lyric poems, and it is in The Bridge where he has achieved maturity in the use of it. That's why Lewis regards The Bridge as Crane's "mensis mirabilis, what the whole period of the visionary lyric had prepared him for" (1967, p. 215). With the employment of the logic of metaphor in The Bridge, Crane has demonstrated "his ability to 
incorporate into poetry a whole sphere of contemporary experience" (Luytens, 1960, p. 99). It is where "his greatness lies” (Luytens, 1960, p. 99). Arpad believes that in The Bridge, Crane is actually in a dilemma: the national ideal in America "saw beauty, good, and truth only in material objects ... the poetic ideal saw these in spiritual objects...” (1967, p. 81). To resolve this conflict and combine them, Crane decides to celebrate the national ideal "by holding up for public acclaim a non-spiritual object" (1967, p. 81), namely, the Brooklyn Bridge $^{9}$ (It is also at this point where Crane is separated from most romantics. For them, "Existence is divided into two realms, heaven and earth, supernatural and natural, the "real” world and the derived world" (Miller, 1965, p. 1).) With his logic of metaphor, the Brooklyn Bridge "is at once both reality and representation, both symbol and substance" (Wargacki, 2006, p. 333). Connecting America's present and past, it "functions as a means of spiritual renewal and transformation” (Wargacki, 2006, p. 333), or a means to prevent America from falling into the abyss of materialistic corruption. To put it simply, Crane has integrated his urban experiences into The Bridge, presenting his own unique poetic vision of his country. Partially concurring with Lefebvre, Crane seems to shatter into pieces the representations of space and his representational space and reorganize them into his poetic vision. Herbert A. Leibowitz considers Crane's poetic vision his own "private truth-the absolute, untranslatable, unique truth" (1968, p. ii). Crane has articulated for his belief that after having read The Bridge, his fellow Americans will see the pathway to God, and above all, the possibility of reconnecting America with its history and rescuing it from the contaminations of capitalism and commercialism. We have to note that Crane is proposing his own personal vision on the basis of the logic of metaphor, not formulating a remedial policy for America. In other words, in The Bridge, Crane's ideal America is actually a visionary world, which should not be bound by any pragmatic, real-life considerations. Therefore, Harold Bloom views the poet as "a prophet of American Orphism,” and his efforts in The Bridge, “an American Gnostic Quest” (1986, p. 2). It is precisely the reason why Crane has managed to superimpose representations of space onto representational space. And it is also the reason why the inner logic of capitalism Lefebvre has perceived in urban space does not apply to Crane's poetic vision.

\section{Conclusion}

For some critics, Crane’s The Bridge may not be a phenomenal success. For instance, James G. Southworth thinks that in The Bridge, Crane "gave us rhetoric instead of poetry" (1950, p. 169). However, the unique success of this poem lies in Crane's treatment of the cityscape of New York and the image of the Brooklyn Bridge. Lefebvre divides urban space into the categories of representational space and representations of space. In The Bridge, Crane has surrounded certain representations of space, like the Brooklyn Bridge and the subway, in representational space, blurring the distinction between. This is Crane's unique vision of America, his poetic solution to America's problem of commercialization.

\section{References}

“Brooklyn Bridge”. The Encyclopedia Americana. (1982).

Archer, J. (2008). Suburban aesthetics is not an oxymoron. In A. Blauvelt (Ed.), Worlds away: New suburban landscape (pp.

${ }^{9}$ L. S. Dembo takes notice of the influence of the Platonic idea of the Absolute on Crane. For him, Crane, deciding on the central image of the Brooklyn Bridge, has commenced "a quest for a logos in which the Absolute that he has known in his imagination will be made intelligible to the world." See L. S. Dembo, Hart Crane's "Sanskrit Charge”, p. 9. 
129-146). Minneapolis: Walker Art Center.

Arpad, J. J. (1967). Hart Crane’s Platonic myth: The Brooklyn Bridge. American Literature, 39(1), 75-86.

Bachelard, G. (1994). The poetics of space. Boston: Beacon Press.

Bloom, H. (1986). Hart Crane. New York: Chelsea House.

Buelens, G. (1992). The American poet and his city: Crane, Williams and Olson. Perceptions of reality in American poetry. English Studies, 73(3), 248-263.

Butterfield, R. W. (1969). Broken arc: A study of Hart Crane. Edinburgh: Oliver and Boyd.

Castells, M. (1977). The urban question: A Marxist approach. London: Edward Arnold.

Chiou, Y. B. (2009). Mutability and immutability: Space, body, and political economy in Tien-Hsin Chu's "ancient capital”. Chung-Wai Literary Monthly, 35(4), 56-94.

Clarke, P. W. (2003). The economic currency of architectural aesthetics. In A. R. Cuthbert (Ed.), Designing cities: Critical readings in urban design (pp. 28-44). Oxford: Blackwell Publishing.

Crane, H. (1930). The Bridge. New York: Horace Liveright.

Crane, H. (1952). The letters of Hart Crane. New York: Hermitage House.

Crane, H. (1966). The complete poems and selected letters and prose of Hart Crane. New York: Anchor.

Current, R. N., Williams, T. H., \& Freidel, F. (1965). American history: A survey. New York: Alfred A. Knopf.

Dembo, L. S. (1960). Hart Crane's “Sanskrit charge”. Ithaca, N.Y.: Cornell University Press.

Dickie, M. (1985). The backward flight of The Bridge. American Literature, 57(1), 79-97.

Giles, P. (1986). Hart Crane: The contexts of The Bridge. Cambridge: Cambridge University Press.

Harvey, D. (1996). Justice, nature, and the geography of difference. Oxford: Blackwell.

Jackson, K. T. (1985). Crabgrass frontier: The suburbanization of the United States. New York: Oxford University Press.

Jenkins, C. (1971). Architecture 2000: Predictions and methods. New York: Praeger.

Johnston, J. H. (1984). The poet and the city: A study in urban perspectives. Athens, Georgia: University of Georgia Press.

Kaiser, E. J., Godschalk, D. R., \& Chapin, F. S. (1995). Urban land use planning. Urbana and Chicago: University of Illinois Press.

King, R. J. (1988). Urban design in capitalist society. Environment and Planning D: Society and Space, 6(4), 445-474.

Lefebvre, H. (1991). The production of space. Oxford and Cambridge: Basil Blackwell.

Lefebvre, H. (1996). Writings on cities. Oxford and Cambridge: Basil Blackwell.

Lefebvre, H. (2003). The urban revolution. Minneapolis: University of Minnesota Press.

Leibowitz, H. A. (1968). Hart Crane: An introduction to the poetry. New York and London: Columbia University Press.

Lewis, R. W. B. (1967). The poetry of Hart Crane. Princeton, N. J.: Princeton University Press.

Luytens, D. B. (1960). The creative encounter. London: Secker and Warburg.

Marx, K., \& Friedrich, E. (1992). The Communist Manifesto. Oxford: Oxford University Press.

Marx, L. (1964). The machine in the garden: Technology and the pastoral ideal in America. New York: Oxford University Press.

Mclellan, D. (1992). Introduction. In K. Marx, F. Engels, and D. Mclellan (Eds.), The Communist Manifesto (pp. vii-xvii). Oxford: Oxford University Press.

Merrifield, A. (2002). Metromarxism: A Marxist tale of the city. New York: Routledge.

Miller, J. H. (1965). Poets of reality: Six twentieth-century writers. Cambridge, Mass: Harvard University Press.

Monacell, P. (2011). In the American grid: Modern poetry and the suburbs. Journal of Modern Literature, 35(1), 122-142.

Moudon, A. V. (2003). A Catholic approach to organizing what urban designers should know. In A. R. Cuthbert (Ed.), Designing cities: Critical readings in urban design (pp. 62-86). Oxford: Blackwell Publishing.

Mumford, L. (1945). City development: Studies in disintegration and renewal. New York: Harcourt, Brace, and Company.

Nietzsche, F. (1954). Portable Nietzsche. New York: Viking.

Norberg-Schulz, C. (2003). The phenomenon of place. In A. R. Cuthbert (Ed.), Designing cities: Critical readings in urban design (pp. 116-127). Oxford: Blackwell Publishing.

Paul, S. (1972). Hart's Bridge. Chicago: University of Illinois Press.

Quinn, V. (1963). Hart Crane. New York: Twayne.

Scott, A. J., \& Roweis, S. T. (1977). Urban planning in theory and practice: A reappraisal. Environment and Planning A, 9(10), 1097-1119.

Simmel, G. (1990). The philosophy of money. London: Routledge.

Smith, N. (2003). The urban revolution. Minneapolis: University of Minnesota Press.

Soja, E. W. (1989). Postmodern geographies: The reassertion of space in critical social theory. London and New York: Verso. 
Southworth, J. G. (1950). Some American modern poets. Oxford: Basil Blackwell.

Staler, S. (2010). Subway ride and subway system in Hart Crane’s “The Tunnel”. Journal of Modern Literature, 33(2), 70-91.

Tashijian, D. (1975). Skyscraper primitives: Dada and the American avant-garde 1910-1925. Middleton, CT: Wesleyan University Press.

Uroff, M. D. (1974). Hart Crane: The patterns of his poetry. Urbana, Chicago and London: University of Illinois Press.

Versluys, K. (1987). The poet in the city: Chapters in the development of urban poetry in Europe and the U.S. (1800-1930). Tübingen: Gunter Narr Verlag.

Wargacki, J. P. (2006). “The "logic of metaphor” at work: Hart Crane’s Marian metaphor in The Bridge. Religion and the Arts, 10(3), 329-354.

Weber, B. (1948). Hart Crane: A biographical study and critical study. New York: Russell and Russell.

Zukin, S. (2003). The urban landscape. In A. R. Cuthbert (Ed.), Designing cities: Critical readings in urban design (pp. 177-189). Oxford: Blackwell Publishing. 